\title{
Temporal genetic variation in populations of Diplodus sargus from the SW Mediterranean Sea
}

\author{
M. González-Wangüemert ${ }^{1, *}$, Á. Pérez-Ruzafa², F. Cánovas³, J. A. García-Charton², \\ C. $\operatorname{Marcos}^{2}$ \\ ${ }^{1}$ Centro de Investigação em Biodiversidade e Recursos Genéticos (CIBIO), Universidade do Porto, \\ Campus Agrário de Vairão, R. Monte-Crasto, 4485-661 Porto, Portugal \\ ${ }^{2}$ Departamento de Ecología e Hidrología, Facultad de Biología, Universidad de Murcia, Campus de Espinardo, \\ 30100 Murcia, Spain \\ ${ }^{3}$ Departamento de Zoología y Antropología Física, Facultad de Veterinaria, Universidad de Murcia, Campus de Espinardo, \\ 30100 Murcia, Spain
}

\begin{abstract}
Population genetic studies on white sea bream Diplodus sargus have revealed different patterns in the subdivision of populations in the Mediterranean Sea. However, the stability of observed allele frequencies over time remains poorly tested. The aim of this study was to show that the genetic structure of $D$. sargus could significantly change over time by analysing temporal variations in allozymes. In order to determine temporal variation in the genetic structure of 5 natural D. sargus populations in the SW Mediterranean, we screened 14 allozyme loci. Our main finding was the significant genotypic differentiation among cohorts (year-classes) in the Guardamar $\left(F_{\mathrm{ST}}=0.012\right.$; $\mathrm{p}<0.001)$ and Cape of Palos $\left(F_{\mathrm{ST}}=0.008 ; \mathrm{p}<0.001\right)$ populations. The differentiation observed in the present study when considering pair-wise comparisons between cohorts is similar to that of all populations throughout the Mediterranean Sea. Our results suggest that microgeographical variations, also known as 'chaotic genetic patchiness', could occur in D. sargus populations from the SW Mediterranean. The recruitment of genetically variable cohorts at 1 site each year may account for these variations. We also discussed alternative explanations for this genetic pattern. This study confirms the importance of understanding the ecology, behaviour and environment of fish populations when investigating population genetic structure. Our results also highlight the importance of incorporating temporal samples when conducting population structure studies.
\end{abstract}

KEY WORDS: Temporal change · Allozymes · Cohort · Recruitment - Marine fish · Dispersal · White sea bream

Resale or republication not permitted without written consent of the publisher

\section{INTRODUCTION}

Many marine fishes exhibit high dispersal potential and a large population size and, as a consequence, one usually expects the degree of genetic differentiation among populations to be low (Bernal-Ramírez et al. 2003). Nevertheless, such low genetic differentiation can account for the relationship between speciation and dispersal/population dynamics in marine species (Domingues et al. 2006). In fact, one may interpret genetic differentiation among populations in terms of population isolation, reduced gene flow, genetic drift and natural selection (González-Wangüemert et al.
2004, Bargelloni et al. 2005, González-Wangüemert et al. 2006a). However, questions often arise regarding the biological significance of such differentiation, partly since the temporal stability of the observed pattern is unknown (Waples 1998). Most of the available research is limited in terms of its description and discussion of observed genetic patterns. These studies assume that observed patterns will remain stable over time, and that variable factors have little or no effect over relatively short time periods (Barcia et al. 2005). However, some studies have documented the relevance of long-term genetic stability research, particularly in the context of understanding which factors 
have led to the establishment of observed patterns (Barcia et al. 2005).

Theoretically, temporal variations in allele frequencies may be the consequence of either selection in larval populations (Johnson \& Black 1982, Lundy et al. 2000, Bernal-Ramírez et al. 2003) and/or large variations in the reproductive success of individuals (genetic drift) (Lenfant \& Planes 2002). An alternative explanation could be that temporal genetic variance is a by-product of large sampling errors engendered by sweepstake reproductive success on behalf of a minority of individuals (Hedgecock 1994). The combination of high reproductive output and high rates of failure during early lifehistory stages means that only a few adults may be responsible for much of the recruitment during any particular season. Such variance in reproductive success would limit effective population sizes, potentially resulting in chaotic genetic patchiness (Johnson \& Black 1982, Larson \& Julian 1999, Bernal-Ramírez et al. 2003) that is temporally unstable. Temporal variance in allelic frequencies may also result from the stochastic nature of reproductive activity and oceanographic conditions conducive to fertilization, larval development, retention and recruitment (Hedgecock 1994, Man \& Buxton 1998, Lenfant \& Planes 2002). Recent studies indicated that larvae are capable of recruiting back to their source population (Swearer et al. 2002), which can also affect the genetic structure of populations.

The purpose of the present study was to assess the stability of the genetic structure of white sea bream Diplodus sargus by analyzing allozyme data from 4 year-classes of 5 Mediterranean populations, and to discuss the possible causes of the patterns observed.

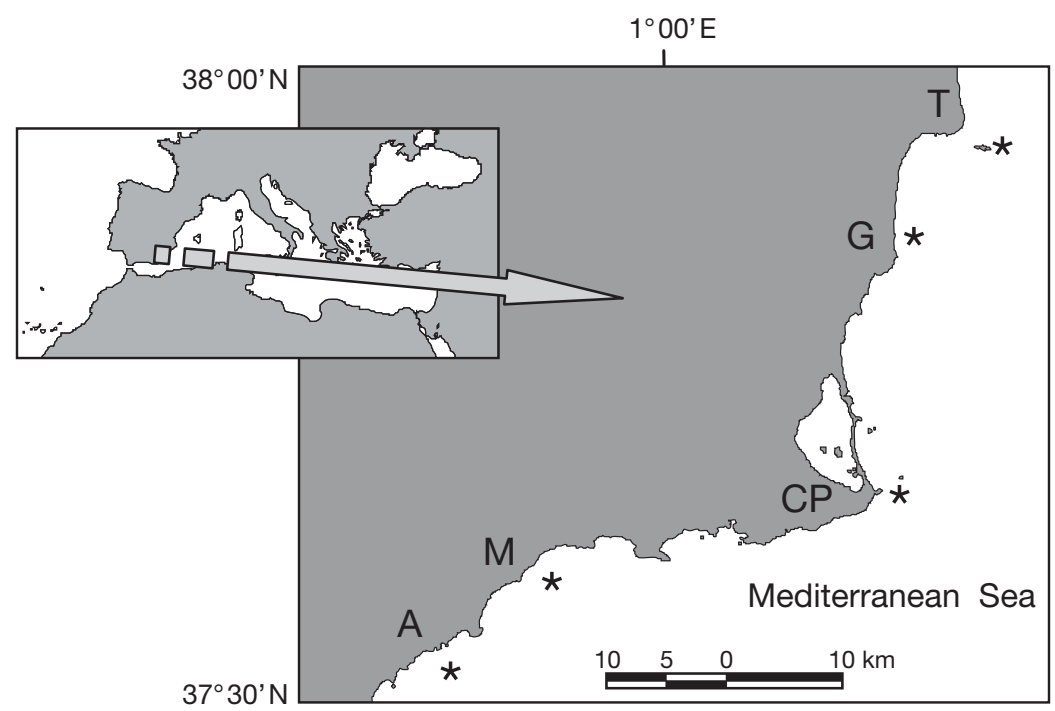

Fig. 1. Diplodus sargus. The 5 sampling sites of the present study. A: Águilas; CP: Cape of Palos; G: Guardamar, M: Mazarrón; T: Tabarca

\section{MATERIALS AND METHODS}

Species. Diplodus sargus is a commercial fish that occurs throughout the Mediterranean Sea and along the West-African coast down to South Africa (Fisher et al. 1987). Adults spawn in the open sea from March to June, and eggs are reported to occur in surface waters down to depths of $5 \mathrm{~m}$. Larvae spend $28( \pm 3) \mathrm{d}$ in the pelagic environment, prior to settlement in very shallow habitats in mid-June. They remain in this habitat for $1 \mathrm{yr}$ until reaching 80 to $100 \mathrm{~mm}$ in length, and then migrate to deeper habitats (Vigliola 1998).

Sampling. A total of 1249 specimens of Diplodus sargus were captured from the eastern Spanish Mediterranean between 1999 and 2000 (Fig. 1). Localities included 2 marine reserves (Tabarca Island and Cape of Palos-Hormigas Islands) and 3 neighbouring nonprotected areas (Águilas, Mazarrón and Guardamar) in the Mediterranean Sea. Fish were frozen after capture, transported to the laboratory and kept at $-40^{\circ} \mathrm{C}$ until dissection. Liver and muscle were extracted from each specimen and kept at $-70^{\circ} \mathrm{C}$ until analysis.

Demographic analysis. We used otoliths (sagittae) to provide estimates of individual fish ages and to assign each fish to a single cohort by counting the number of slow-growing winter zones. Each otolith was counted twice by 2 different observers, and a third count was made in the case of conflict. Fishes with otoliths showing inconsistent patterns (11) were excluded from any further analysis. Final analysis involved 1238 individuals that had no ambiguities in terms of otolith reading. The term 'cohort' usually refers to individuals that recruit over a short period of time. In this study a cohort was equivalent to a yearclass, because Diplodus sargus settles once a year within a 1 mo period. Cohorts were labelled according to the year they settled, e.g. 'Cohort 99' means the cohort whose individuals settled in 1999.

Electrophoresis. Samples were homogenised in an equal volume of Tris/Citrate buffer (pH 9.0). Homogenates were centrifuged at $7000 \times g$ for $12 \mathrm{~min}$ at $4^{\circ} \mathrm{C}$, and the supernatant was stored at $-80^{\circ} \mathrm{C}$. We performed starch gel electrophoresis according to González-Wangüemert et al. (2004), and chose a set of enzymes with a clear polymorphic zymogram. The loci used for analysis were scored from the following enzyme stains: glucose-6-phosphate isomerase, EC 5.3.1.9 (GPI-1* and $\left.G P I-2^{*}\right)$; phosphoglucomutase, EC 5.4.2.1 $\left(P G M^{*}\right)$; phosphogluconate de- 
hydrogenase, EC 1.1.1.44 $\left(P G D H^{*}\right)$; lactate dehydrogenase, EC 1.1.1.27 ( $L D H-1^{*}$ and $\left.L D H-2^{*}\right)$; adenosine deaminase, EC 3.5.4.4 $\left(A D A^{*}\right)$; guanine deaminase, EC 3.5.4.3 $\left(G D A^{*}\right)$; isocitrate dehydrogenase EC 1.1.1.42 (IDH-1* and $\left.I D H-2^{*}\right)$; aspartate aminotransferase EC 2.6.1.1 (AAT-1* and $\left.A A T-2^{*}\right)$; malate dehydrogenase EC 1.1.1.37 (MDH-1* and $\left.M D H-2^{*}\right)$.

Population genetic analysis. We did not take all cohorts into consideration when analyzing genetic structure because sample number differed greatly for each cohort. Firstly, we studied the genetic variability between year-classes in each population using data from 4 cohorts (1995, 1996, 1997, and 1998); secondly, we used only 3 cohorts (1996, 1997 and 1998) to compare the genetic structure among cohorts and the different populations.

We obtained allelic and genotypic frequencies by counting phenotypes directly from the gels using the GENETIX software package (available at www.genetix. univ-montp2.fr/genetix.htm). We calculated the probability of random departure from the Hardy-Weinberg equilibrium and the significance of divergence among groups using the 'exact test' method (Raymond \& Rousset 1995). Values of observed and expected heterozygosity were computed for each cohort from the genotypic frequencies, taking all loci into account.

We calculated F-statistics using the Weir \& Cockerham (1984) method. The $F_{\text {IS }}$ value is the average inbreeding coefficient that reflects the Hardy-Weinberg equilibrium within a group, whereas $F_{\text {ST }}$ values indicate the amount of divergence between groups (defined as cohorts). Probabilities of the random departure of $F$-values from 0 (according to the null hypothesis) were read directly from the distribution of 1000 randomised matrices computed via permutation. We performed this analysis using the $F$-testing procedure of GENETIX, thus allowing for a significance test to be conducted. We computed Spearman's correlations between $F_{\text {IS, }}$, heterozygosity, the average number of alleles per locus and the abundance of cohorts.

Nei's genetic distances (Nei 1978) and Cavalli-Sforza distances between pair-wise samples were calculated, and the resulting matrix was clustered using UPGMA and neighbour-joining algorithms respectively ( $\mathrm{R}$ statistical software package; R Development Core Team 2005). According to the null hypothesis, we directly calculated probabilities of random departure from 0 for genetic distance values from the distribution of 1000 randomised matrices computed via permutation (GENETIX).

We considered individual probabilities (as described by Cornuet et al. 1999) in order to determine the most likely geographic origin of each fish sampled, and to assign the stock origin of a fish with genotypic data only. We assigned each individual to the sample to which it had the highest 'probability of belonging'. We used the program GENECLASS version 1.0 (Cornuet et al. 1999) for these calculations, and as recommended by these authors we selected the 'Bayesian approach'. To decrease bias we chose the 'leave-one-out' option, whereby the assigned individual is not included in the estimation of allele frequencies. We also compared genetic differences using principal component analysis (PCA) of allelic frequencies. These analyses were described by She et al. (1987) and calculated using R statistical software (R Development Core Team 2005).

\section{RESULTS}

\section{Demographic structure}

The age structure of SW Mediterranean white sea bream populations revealed strong variation in the abundance of each cohort (Fig. 2). Most individuals were younger than 10 years of age: only a few individuals exceeded this age. Fishes from Tabarca Island were the oldest. This age structure is considered typical for target species and, in fact, is probably a consequence of fishing. The largest and oldest individuals were found within the protected populations (Tabarca and Cape of Palos marine reserves), because these are not removed by fishing. Five cohorts $(95,96,97,98$ and 99) accounted for 69 to $81.6 \%$ of the total population; however, in the Tabarca population, these cohorts accounted for only $54.5 \%$.

\section{Genetic variation between cohorts in each population}

Mean heterozygosity was high for all cohorts in each sample (Table 1). Observed heterozygosity and the average number of alleles did not correlate with abundance in each cohort. The average number of alleles only correlated significantly with the number of individuals per cohort in the Mazarrón population $(\rho=1, p<0.05)$.

Cohorts exhibited a significant deviation from the Hardy-Weinberg equilibrium owing to heterozygote deficits. However, some loci showed a (non-significant) heterozygote excess: $L D H-1^{*}, M^{*} H_{-1}{ }^{*}$ (Cohort 95 Águilas) and GDA* (Cohort 97 Águilas) loci, PGM* (Cohort 96 Cape of Palos), MDH-1* , MDH-2* (Cohort 95 Cape of Palos), PGI-2* ${ }^{*}$ ADA* (Cohort 98 Cape of Palos) and $G D A^{*}$ (Cohort 95, 97, 98 Cape of Palos) loci, LDH-2* (Cohorts 96 and 97 Guardamar), LDH-1* (Cohort 98 Guardamar) and GDA* (Cohort 95 Guardamar) loci, and the $M D H-1^{*}$ (Cohort 95 Tabarca) locus. Only the LDH-2* (Cohorts 95, 96 and 97 Mazarrón) locus exhibited a significant heterozygote excess. 


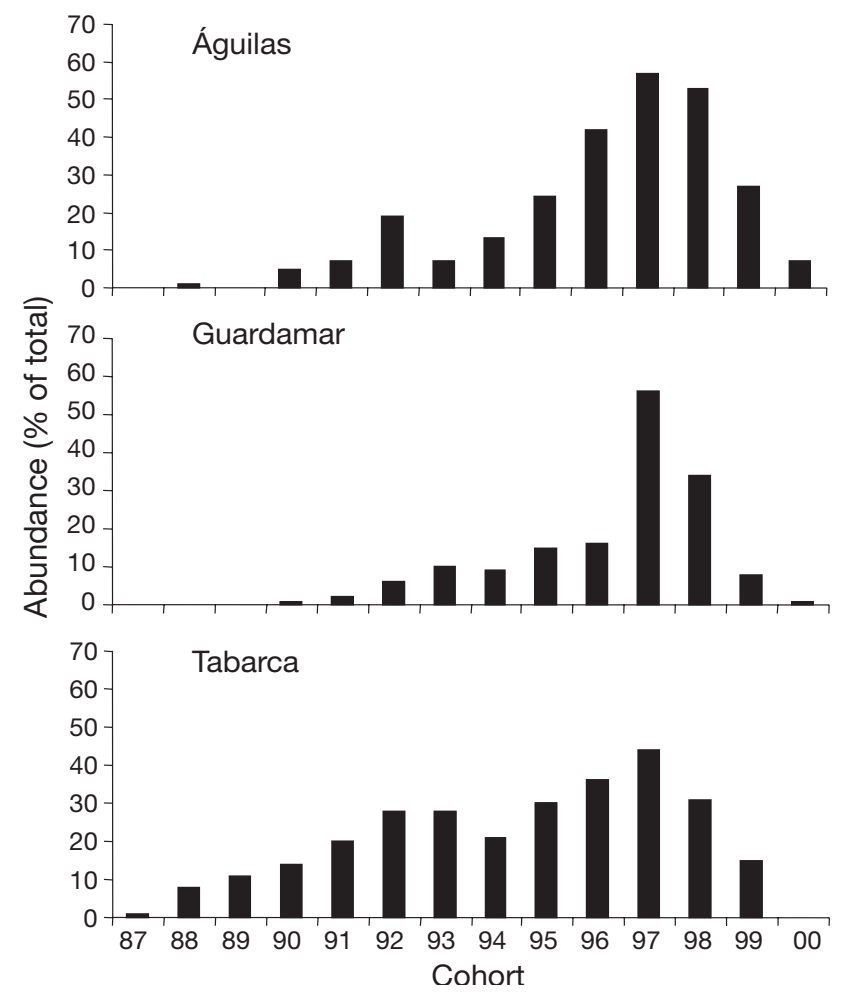

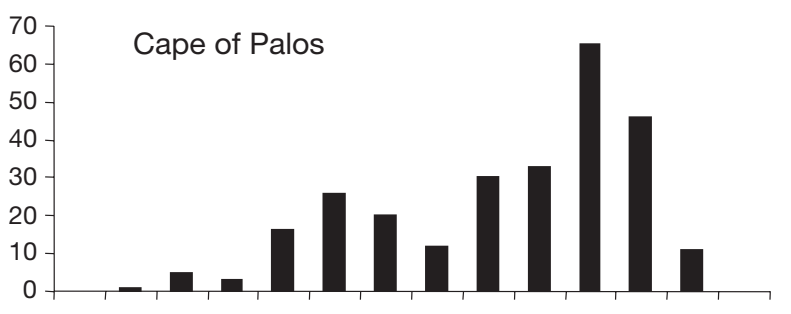

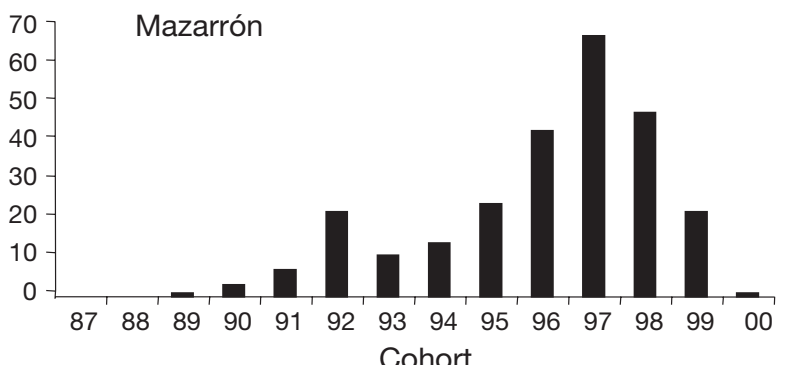

Fig. 2. Diplodus sargus. Demographic structure of populations in the SW Mediterranean (Spain)
Table 1. Diplodus sargus. Genetic diversity indices for each cohort and overall cohorts. N: sample size; $H_{\mathrm{O}}$ : observed heterozygosity; $H_{\mathrm{E}}$ : expected heterozygosity; $F_{\text {IS }}$ : Wright's inbreeding index; ${ }^{*}$ : $\mathrm{p}<0.001$

\begin{tabular}{|c|c|c|c|c|c|c|}
\hline Population & Cohort & $\mathrm{N}$ & $H_{\mathrm{O}}$ & $H_{\mathrm{E}}$ & $\begin{array}{c}\text { Allele } \\
\text { average }\end{array}$ & $F_{\mathrm{IS}}$ \\
\hline \multirow[t]{5}{*}{ Águilas } & 95 & 24 & 0.4171 & 0.5642 & 4.0000 & $0.2815^{*}$ \\
\hline & 96 & 42 & 0.3737 & 0.5468 & 4.5000 & $0.3262^{*}$ \\
\hline & 97 & 57 & 0.4012 & 0.5653 & 4.7143 & $0.2977^{*}$ \\
\hline & 98 & 53 & 0.3858 & 0.5611 & 4.4286 & $0.3196^{*}$ \\
\hline & Overall & 166 & 0.3923 & 0.5650 & 5.0714 & $0.3097^{*}$ \\
\hline \multirow[t]{5}{*}{ Cape of Palos } & 95 & 30 & 0.4194 & 0.5790 & 4.2857 & $0.2914^{*}$ \\
\hline & 96 & 33 & 0.4157 & 0.5193 & 4.5000 & $0.2144^{*}$ \\
\hline & 97 & 65 & 0.4402 & 0.5498 & 4.7143 & $0.2068^{*}$ \\
\hline & 98 & 46 & 0.4030 & 0.5182 & 4.2857 & $0.2328^{*}$ \\
\hline & Overall & 174 & 0.4221 & 0.5500 & 5.0000 & $0.2352^{*}$ \\
\hline \multirow[t]{5}{*}{ Guardamar } & 95 & 15 & 0.3762 & 0.5844 & 4.4286 & $0.3871^{*}$ \\
\hline & 96 & 16 & 0.3567 & 0.5325 & 3.9286 & $0.3575^{*}$ \\
\hline & 97 & 56 & 0.3771 & 0.5536 & 5.0714 & $0.3270^{*}$ \\
\hline & 98 & 34 & 0.3921 & 0.5850 & 5.0000 & $0.3435^{*}$ \\
\hline & Overall & 121 & 0.3786 & 0.5775 & 5.2857 & $0.3429^{*}$ \\
\hline \multirow[t]{5}{*}{ Mazarrón } & 95 & 24 & 0.3804 & 0.5660 & 4.0714 & $0.3472^{*}$ \\
\hline & 96 & 43 & 0.3695 & 0.5590 & 4.2143 & $0.3498^{*}$ \\
\hline & 97 & 68 & 0.3381 & 0.5446 & 4.9286 & $0.3856^{*}$ \\
\hline & 98 & 48 & 0.3539 & 0.5616 & 4.5714 & $0.3789^{*}$ \\
\hline & Overall & 183 & 0.3556 & 0.5616 & 5.1429 & $0.3698^{*}$ \\
\hline \multirow[t]{5}{*}{ Tabarca } & 95 & 30 & 0.3418 & 0.5343 & 4.7143 & $0.3751^{*}$ \\
\hline & 96 & 34 & 0.3149 & 0.5875 & 5.1429 & $0.4756^{*}$ \\
\hline & 97 & 44 & 0.3101 & 0.5571 & 4.7857 & $0.4229^{*}$ \\
\hline & 98 & 31 & 0.3078 & 0.5341 & 4.3571 & $0.4373^{*}$ \\
\hline & Overall & 139 & 0.3178 & 0.5652 & 5.4286 & $0.4407^{*}$ \\
\hline
\end{tabular}

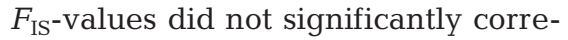
late with the abundance of each cohort, with the exception of those cohorts from Mazarrón $(\rho=1, p<0.05)$. The overall genetic differentiation between cohorts was not significant at Águilas, Mazarrón and Tabarca; however, the genetic differentiation between cohorts was significant at Cape of Palos $\left(F_{\mathrm{ST}}=0.008 ; \mathrm{p}<0.001\right)$ and Guardamar $\left(F_{\mathrm{ST}}=0.012 ; \mathrm{p}<0.001\right)$. Nei's genetic distances (based on allelic frequencies) were significant between all cohorts at Cape of Palos, Guardamar and Tabarca (except between Cohorts 96 and 97). Populations from Águilas and Mazarrón exhibited significant genetic distances between some cohorts only.

\section{Genetic variation between cohorts from different populations}

Estimates of genetic differentiation between pairs of cohorts produced significant $F_{\mathrm{ST}}$ and genetic distance values in all but a few cases (Table 2). Genetic distance dendrograms did not reveal any structure in cohort grouping related to age or abundance (Fig. 3). The results 
of PCA of allele frequency data revealed a cohort distribution that agrees with those obtained from genetic distances. The first and second axes explained $34.3 \%$ of total variation, and separated Cape of Palos and Mazarrón cohorts from the others. Cohorts from the Cape of Palos were clearly separated from the Mazarrón cohorts and Cohort 98 from Tabarca along the first $(x$-)axis, which were in turn separated from the Águilas, Guardamar and remaining Tabarca cohorts along the second ( $y$-)axis (Fig. 4).

Table 3 gives the results of assignment tests. These revealed that approximately $15 \%$ of individuals were correctly assigned to the sample from which they originated. Among those individuals assigned to a different sample, $25 \%$ were assigned to the same population but from another year, and $20 \%$ were assigned to the correct year but to samples from different populations.

\section{DISCUSSION}

The main result of this study was the highly significant genotypic differentiation among cohorts in the Guardamar $\left(F_{\mathrm{ST}}=0.012 ; \mathrm{p}<0.001\right)$ and Cape of Palos $\left(F_{\mathrm{ST}}=0.008 ; \mathrm{p}<0.001\right)$ populations. Similar results $\left(F_{\mathrm{ST}}\right.$ $=0.008 ; \mathrm{p}<0.001)$ were obtained for Diplodus sargus cohorts from Banyuls (NW Mediterranean) (Lenfant \& Planes 2002). This level of genetic differentiation contrasts with previous studies on the spatial genetic structure of the same species in populations from Lion's Gulf and the Ligurian Sea (NW Mediterranean; $\left.F_{\mathrm{ST}}=0.007\right)$ and the Murcia and Alicante populations (SW Mediterranean; $F_{\mathrm{ST}}=0.006$ ), among which Lenfant \& Planes (1996) and González-Wangüemert et al. (2004) found somewhat limited differentiation. Bargelloni et al. (2005) observed similar limited differentia- tion for $D$. sargus throughout the Mediterranean Sea and Atlantic Ocean $\left(F_{\mathrm{ST}}=0.009\right)$; however, in this latter case, the $F_{\mathrm{ST}}$ value was not significant. In another case, Lenfant \& Planes (1996) found no divergence among a number of sites separated by several hundred kilometres. In terms of pair-wise comparisons between cohorts, results from previous studies on the genetic differentiation of $D$. sargus throughout the Mediterranean Sea are similar to those obtained in the present study, which raises questions on the value and origin of genetic divergence observed between distant populations (Lenfant \& Planes 1996, González-Wangüemert et al. 2004, Pérez-Ruzafa et al. 2006, GonzálezWangüemert et al. 2006b).

Large variance in reproductive success, reported for many marine organisms (Ruzzante et al. 1996, Li \& Hedgecock 1998), could perhaps determine the population genetic structure of white sea bream. Man \& Buxton (1998) demonstrated that maturation is related to water temperature in Diplodus sargus capensis and $D$. sargus hottentotus. This variable may act as a limiting factor on the reproduction rate of white sea bream. However, available data on temperature in the area studied (obtained from the NOAA via www.noaa.gov) showed no significant variations for a range of SWMediterranean populations during the reproductive months covered by the present study.

An alternative explanation for the variance in reproductive success could be the alteration of population size, local retention, local adaptation and random or selective post-settlement mortality (Ruzzante et al. 1996, Lundy et al. 2000, Lenfant \& Planes 2002). In this study, the use of allozyme markers (known as 'selective markers') could account for the observed genetic differentiation between cohorts, which may have resulted from post- or pre-settlement fish mortality (known to be

Table 2. Diplodus sargus. Estimates of genetic differentiation between pairs of samples: $F_{\mathrm{ST}}$ (below diagonal) and genetic distances (Nei 1978) (above diagonal). A: Águilas; CP: Cape of Palos; G: Guardamar, M: Mazarrón; T: Tabarca; year of settlement is indicated for each cohort. For clarity, non-significant values are in bold $(p<0.01)$

\begin{tabular}{|c|c|c|c|c|c|c|c|c|c|c|c|c|c|c|c|}
\hline & A96 & A97 & A98 & CP96 & CP97 & CP98 & G96 & G97 & G98 & M96 & M97 & M98 & T96 & T97 & T98 \\
\hline A96 & 0 & -0.0040 & 0.0010 & 0.0070 & 0.0070 & 0.0140 & 0.0580 & 0.0070 & 0.0120 & 0.0050 & 0.0130 & 0.0150 & 0.0120 & 0.0060 & 0.0120 \\
\hline A97 & -0.0040 & 0 & -0.0010 & 0.0070 & 0.0060 & 0.0120 & 0.0420 & 0.0050 & 0.0140 & 0.0060 & 0.0110 & 0.0170 & 0.0100 & 0.0060 & 0.0080 \\
\hline A98 & -0.0028 & -0.0040 & 0 & 0.0070 & 0.0110 & 0.0160 & 0.0410 & 0.0070 & 0.0060 & 0.0050 & 0.0140 & 0.0130 & 0.0060 & 0.0070 & 0.0040 \\
\hline СР96 & 0.0024 & 0.0034 & 0.0025 & 0 & 0.0070 & 0.0070 & 0.0680 & 0.0100 & 0.0240 & 0.0160 & 0.0190 & 0.0170 & 0.0160 & 0.0120 & 0.0180 \\
\hline CP97 & 0.0030 & 0.0027 & 0.0060 & 0.0032 & 0 & 0.0150 & 0.0480 & 0.0100 & 0.0230 & 0.0070 & 0.0140 & 0.0230 & 0.0110 & 0.0170 & 0.0150 \\
\hline CP98 & 0.0086 & 0.0076 & 0.0112 & 0.0029 & 0.0111 & 0 & 0.0650 & 0.0130 & 0.0300 & 0.0130 & 0.0190 & 0.0250 & 0.0150 & 0.0170 & 0.0260 \\
\hline G96 & 0.0366 & 0.0244 & 0.0236 & 0.0482 & 0.0323 & 0.0471 & 0 & 0.0470 & 0.0350 & 0.0380 & 0.0480 & 0.0680 & 0.0390 & 0.0470 & 0.0530 \\
\hline G97 & 0.0018 & 0.0012 & 0.0023 & 0.0054 & 0.0059 & 0.0080 & 0.0292 & 0 & 0.0090 & 0.0070 & 0.0100 & 0.0170 & 0.0090 & 0.0020 & 0.0140 \\
\hline G98 & 0.0048 & 0.0064 & 0.0008 & 0.0162 & 0.0147 & 0.0220 & 0.0169 & 0.0037 & 0 & 0.0130 & 0.0140 & 0.0230 & 0.0130 & 0.0100 & 0.0150 \\
\hline M96 & 0.0000 & 0.0010 & 0.0001 & 0.0094 & 0.0033 & 0.0085 & 0.0209 & 0.0022 & 0.0053 & 0 & 0.0000 & 0.0040 & 0.0060 & 0.0130 & 0.0090 \\
\hline M97 & 0.0068 & 0.0058 & 0.0083 & 0.0118 & 0.0089 & 0.0131 & 0.0302 & 0.0048 & 0.0076 & -0.0030 & 0 & 0.0120 & 0.0110 & 0.0130 & 0.0130 \\
\hline M98 & 0.0079 & 0.0093 & 0.0061 & 0.0106 & 0.0153 & 0.0173 & 0.0415 & 0.0095 & 0.0122 & -0.0015 & 0.0060 & 0 & 0.0160 & 0.0220 & 0.0110 \\
\hline T96 & 0.0044 & 0.0033 & 0.0006 & 0.0093 & 0.0059 & 0.0101 & 0.0177 & 0.0032 & 0.0024 & 0.0006 & 0.0049 & 0.0065 & 0 & 0.0040 & 0.0080 \\
\hline T97 & -0.0003 & 0.0008 & 0.0011 & 0.0059 & 0.0103 & 0.0111 & 0.0262 & -0.0024 & 0.0022 & 0.0053 & 0.0066 & 0.0116 & -0.0029 & 0 & 0.0150 \\
\hline T98 & 0.0044 & 0.0020 & -0.0013 & 0.0098 & 0.0088 & 0.0175 & 0.0315 & 0.0066 & 0.0064 & 0.0020 & 0.0059 & 0.0031 & -0.0003 & 0.0058 & 0 \\
\hline
\end{tabular}




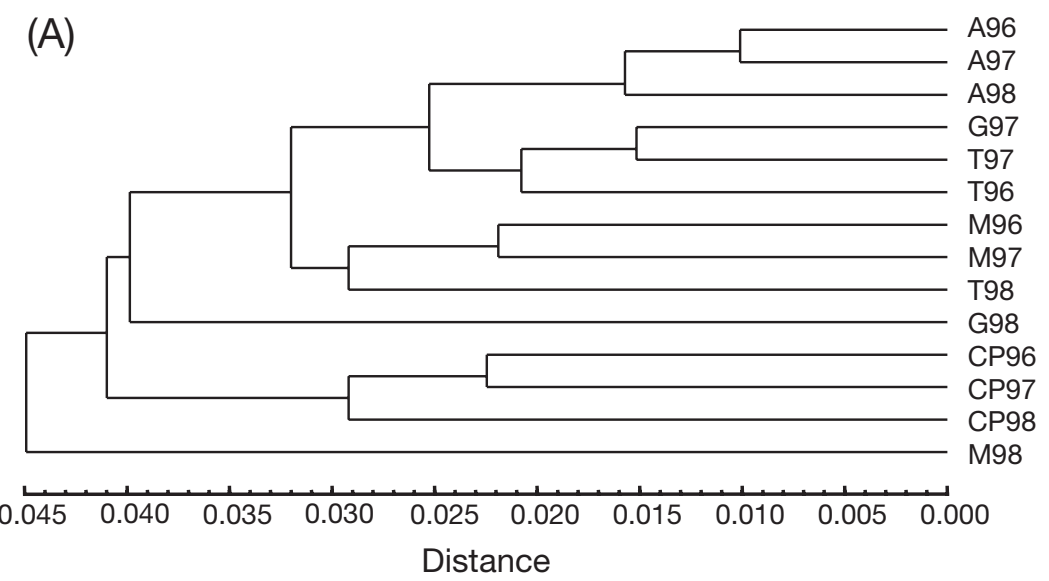

Reproductive success can also be affected by ocean currents. The marine environment is highly unpredictable: the occurrence of intense ocean currents can drive eggs and larvae away from coastal retention areas, resulting in very high mortality rates (Li \& Hedgecock 1998). In any one year, larvae that do survive may derive from the relatively low number of individuals that have, by chance, matched their reproductive activity with oceanographic conditions (Lundy et al. 2000). In this way it is possible for a high variance in reproductive success to result in genetic

(B)

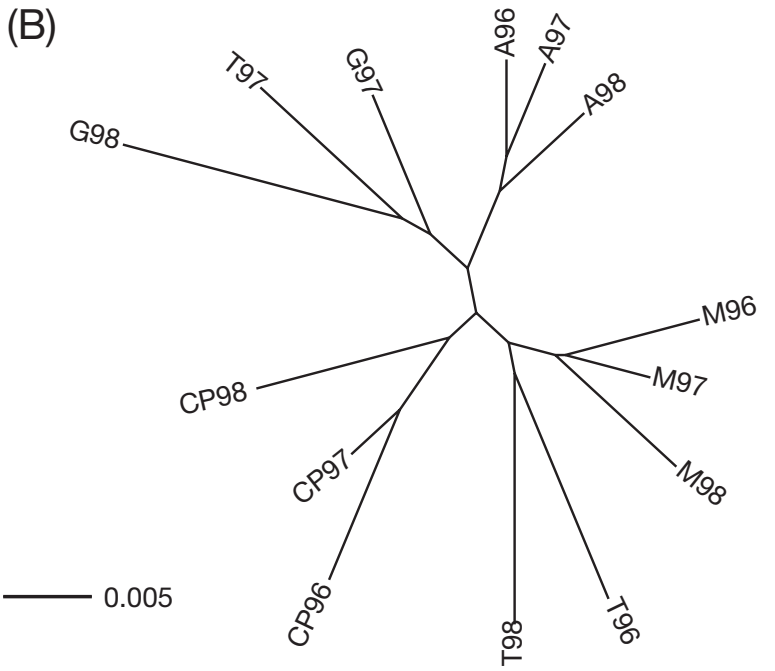

Fig. 3. Diplodus sargus. UPGMA and neighbour-joining plots of genetic distances calculated for 14 allozyme loci among 15 cohorts. (a) Nei (1978) distance; (b) Cavalli-Sforza distance

highly selective processes). It has been shown that allozymes display selective processes in order to favour either the adaptation to changes in salinity or resistance to environmental stress (Dufresne et al. 2002). Although we still know very little about the microevolution of most characters, many studies on selection have demonstrated processes involving only a few loci whereas others have remained neutral (Lenfant \& Planes 2002). In this study, the differentiation observed between cohorts relied on divergence at several loci, and those loci that contributed to significant differentiation varied in pair-wise comparisons. We observed no similar trends in cohorts that might have resulted from selection over time as cohorts grew older. Cluster analysis did not group cohorts according to their age but instead revealed a random organization, as was also demonstrated by other authors studying Diplodus sargus (Lenfant \& Planes 2002). variation among year classes. Our previous research on current patterns shows that oceanographic processes and conditions that affect the reproduction of marine animal life vary not only from one year to another but also within and between seasons in the study zone (González-Wangüemert 2004).

The genetic pattern observed here could imply that microgeographical variations, also known as 'chaotic genetic patchiness', could occur in Diplodus sargus populations in the SW Mediterranean as a consequence of local oceanographic patterns. Such variations may result from the recruitment of genetically variable cohorts at one site each year. However, we cannot verify the second conclusion of Hedgecock's 'sweepstakes' recruitment, which indicates that there should be a decrease in genetic diversity. This conclusion may be

Table 3. Results of assignment tests (\%) conducted using GENECLASS 1.0 (Cornuet et al. 1999)

\begin{tabular}{|c|c|c|c|c|}
\hline & $\begin{array}{l}\text { Assigned } \\
\text { to sample } \\
\text { of origin }\end{array}$ & $\begin{array}{l}\text { Assigned to } \\
\text { population } \\
\text { of origin but } \\
\text { to incorrect } \\
\text { year }\end{array}$ & $\begin{array}{l}\text { Assigned to } \\
\text { correct year } \\
\text { but to another } \\
\text { population }\end{array}$ & $\begin{array}{l}\text { Assigned to } \\
\text { another } \\
\text { population } \\
\text { and in- } \\
\text { correct year }\end{array}$ \\
\hline A96 & 4.8 & 23.8 & 21.4 & 50.0 \\
\hline A97 & 8.8 & 28.1 & 19.3 & 43.9 \\
\hline A98 & 9.3 & 29.6 & 25.9 & 35.2 \\
\hline CP96 & 15.2 & 36.4 & 18.2 & 30.3 \\
\hline CP97 & 18.5 & 26.2 & 21.5 & 33.8 \\
\hline CP98 & 28.3 & 19.6 & 15.2 & 37.0 \\
\hline G96 & 37.5 & 25.0 & 6.3 & 31.3 \\
\hline G97 & 14.3 & 12.5 & 30.4 & 42.9 \\
\hline G98 & 11.8 & 32.4 & 26.5 & 29.4 \\
\hline M96 & 7.0 & 39.5 & 14.0 & 39.5 \\
\hline M97 & 16.2 & 32.4 & 14.7 & 36.8 \\
\hline M98 & 16.7 & 25.0 & 20.8 & 37.5 \\
\hline Т96 & 11.1 & 16.7 & 8.3 & 63.9 \\
\hline T97 & 18.2 & 13.6 & 22.7 & 45.5 \\
\hline T98 & 3.2 & 22.6 & 22.6 & 51.6 \\
\hline Total & 15.0 & 25.0 & 20.0 & 40.0 \\
\hline
\end{tabular}



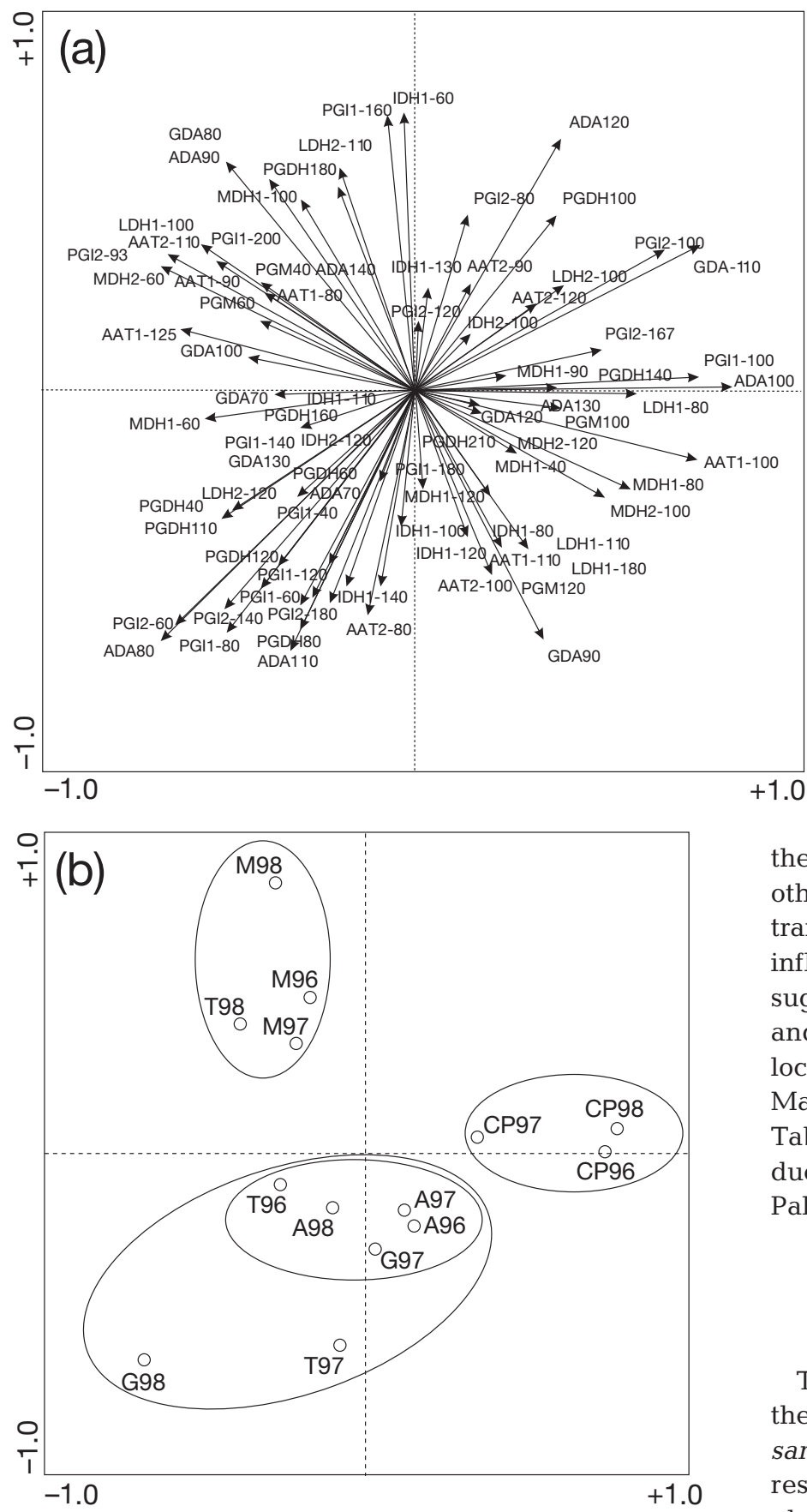

Fig. 4. Diplodus sargus. PCA of allele frequencies of cohorts. (a) Allele distribution. Loci are listed in 'Materials and methods'. (b) Cohort distribution. See Fig. 1 and Table 1 for definition of cohorts

difficult to assess using allozyme data that cover a limited number of alleles. Future molecular genetic analyses using microsatellite markers with a larger number of alleles should help to resolve this issue.

Finally, the assignment test provided a solid demonstration of genetic discontinuities. Most individuals were not correctly assigned to the sample from which they derived. The tendency towards 'mis-assigned' individuals from Tabarca and Guardamar was striking: these individuals were assigned to samples from different populations and to either the correct or incorrect settlement period. Individuals from Águilas, Mazarrón and Cape of Palos showed a higher percentage of correct self-assignment $(35,46$ and $48 \%$ respectively), which may have resulted from a self-recruitment process. This has been previously observed in various fish species (Swearer et al. 2002). Some studies suggest that self-recruitment is higher in populations of low density (Benzie \& Stoddart 1992), which is likely to characterize Águilas and Mazarrón populations as a result of increases in fishing pressures. In fact, some authors have highlighted recent reductions in the density of Diplodus sargus populations at Águilas from 21.1 to 10.8 ind. $\mathrm{m}^{-2}$ (García-Charton et al. 2004). However, the Cape of Palos population is located within a marine reserve where fishery management tools are implemented. Therefore, the self-recruitment at this location must result from other factors. Cape of Palos is considered a faunistic transitional zone between Atlantic and Mediterranean influences (Whitehead et al. 1986). Previous studies suggest that gene flow takes place via pelagic systems and the open sea circulation model, which connect localities to the south of Cape of Palos (Águilas and Mazarrón) with northern areas (Guardamar and Tabarca). This pattern could imply self-recruitment due to the partial oceanographic isolation of Cape of Palos (González-Wangüemert et al. 2004).

\section{CONCLUSIONS}

Temporal differentiation patterns would suggest that the population structure of white sea bream Diplodus sargus in the SW Mediterranean is complex. Our results highlight the need to incorporate temporal samples when conducting studies on population structure, and reinforce the importance of understanding the ecology, behaviour and environment of fish populations when investigating population genetics.

Acknowledgements. We thank 3 anonymous referees for their valuable suggestions. We also thank all volunteers who helped to obtain data on winds and currents, particularly C. Mompeán, A. Herrero, S. Polti and C. Espejo. This research was partially supported by the SENECA Program, University of Murcia (PB/56/FS/02), and a grant from the research group 'Ecología y Ordenación de Ecosistemas Marinos Costeros' (University of Murcia) awarded to M.G.W. 


\section{LITERATURE CITED}

Barcia AR, López GE, Hernández D, García-Machado E (2005) Temporal variation of the population structure and genetic diversity of Farfantepenaeus notialis assessed by allozyme loci. Mol Ecol 14: 2933-2942

Bargelloni L, Alarcon JA, Alvarez MC, Penzo E, Magoulas A, Palma J, Patarnello T (2005) The Atlantic-Mediterranean transition: discordant genetic patterns in two seabream species, Diplodus puntazzo (Cetti) and Diplodus sargus (L.). Mol Phylogenet Evol 36:523-535

Benzie JAH, Stoddart JA (1992) Genetic structure of outbreaking and non-outbreaking crown-of-thorns starfish (Acanthaster planci) populations on the Great Barrier Reef. Mar Biol 112:119-130

Bernal-Ramírez JH, Adcock GJ, Hauser L, Carvalho GR, Smith PJ (2003) Temporal stability of genetic population structure in the New Zealand snapper, Pagrus auratus, and relationship to coastal currents. Mar Biol 142:567-574

Cornuet JM, Piry S, Luikart G, Estoup A, Solignac M (1999) New methods employing multilocus genotypes to select or exclude populations as origins of individuals. Genetics 153: 1989-2000

Domingues VS, Santos RS, Brito A, Almada VC (2006) Historical population dynamics and demography of the eastern Atlantic pomacentrid Chromis limbata (Valenciennes, 1833). Mol Phylogenet Evol 40:139-147

Dufresnes F, Bourget E, Bernatchez L (2002) Differential pattern of spatial divergence in microsatellite and allozyme alleles: further evidence for locus-specific selection in the acorn barnacle, Semibalanus balanoides? Mol Ecol 11: 113-123

Fisher W, Schneider M, Bauchot ML (1987) Fiches FAO d'identification des espèces pour les besoins de la pèche. Méditerranée et Mer Noire (Zone de pèche 37). FAO, Rome

García-Charton JA, Pérez-Ruzafa A, Sánchez-Jerez P, BayleSempere J, Reñones O, Moreno D (2004) Multi-scale spatial heterogeneity, habitat structure, and the effects of marine reserves on Western Mediterranean rocky reef fish assemblages. Mar Biol 144:161-182

González-Wangüemert M (2004) Scales of variability in the genetic structure of SW Mediterranean populations of Diplodus sargus. Genetic effects of fisheries protection in marine reserves. $\mathrm{PhD}$ dissertation, University of Murcia

González-Wangüemert M, Pérez-Ruzafa Á, Marcos C, García-Charton J (2004) Genetic differentiation of Diplodus sargus (Pisces: Sparidae) populations in Southwest Mediterranean. Biol J Linn Soc 82:249-261

González-Wangüemert M, Giménez-Casalduero F, PérezRuzafa Á (2006a) Genetic differentiation of Elysia timida (Risso, 1818) populations in Southwest Mediterranean and Mar Menor coastal lagoon. Biochem Syst Ecol 34:514-527

González-Wangüemert M, Pérez-Ruzafa Á, García Charton JA, Marcos C (2006b) Genetic differentiation and gene flow of two sparidae subspecies, Diplodus sargus sargus and Diplodus sargus cadenati, in Atlantic and SW Mediterranean populations. Biol J Linn Soc 89/4:705-718

Hedgecock D (1994) Does variance in reproductive success limit effective population sizes of marine organisms? In: Beaumont AR (ed) Genetics and evolution of aquatic organisms. Chapman \& Hall, London, p122-134

Johnson MS, Black R (1982) Chaotic genetic patchiness in an intertidal limpet, Siphonaria sp. Mar Biol 70:157-164

Larson RJ, Julian RM (1999) Spatial and temporal genetic patchiness in marine populations and their implications for fisheries management. Calif Coop Ocean Fish Invest Rep 40:94-99

Lenfant P, Planes S (1996) Genetic differentiation of white sea bream within the Lion's Gulf and the Ligurian Sea (Mediterranean Sea). J Fish Biol 49:613-621

Lenfant P, Planes S (2002) Temporal genetic changes between cohorts in a natural population of a marine fish, Diplodus sargus. Biol J Linn Soc 76:9-20

Li G, Hedgecock D (1998) Genetic heterogeneity, detected by PCR-SSCP, among samples of larval pacific oysters (Crassostrea gigas) supports the hyphothesis of large variance in reproductive success. Can J Fish Aquat Sci 55: 1025-1033

Lundy CJ, Rico C, Hewitt GM (2000) Temporal and spatial genetic variation in spawning grounds of European hake (Merluccius merluccius) in the Bay of Biscay. Mol Ecol 9: 2067-2079

Man BQ, Buxton CD (1998) The reproductive biology of Diplodus sargus capensis and D. cervinus hottentotus (Sparidae) off the South-East Cape Coast, South Africa. Cybium 22: $31-47$

Nei M (1978) Estimation of average heterozygosity and genetic distance from a small number of individuals. Genetics 89: 583-590

Pérez-Ruzafa Á, González-Wangüemert M, Lenfant P, Marcos C, García-Charton JA (2006) Effects of fishing protection on the genetic structure of fish populations. Biol Conserv 129: $244-255$

Raymond M, Rousset F (1995) An exact test for population differentiation. Evolution 49:1280-1283

R Development Core Team (2005) R: A language and environment for statistical computing. R Foundation for Statistical Computing, Vienna

Ruzzante DE, Taggart CT, Cook D (1996) Spatial and temporal variation in the genetic composition of a larval cod (Gadus morhua) aggregation: cohort contribution and genetic stability. Can J Fish Aquat Sci 53:2695-2705

She JX, Autem M, Kotulas G, Pasteur N, Bonhomme F (1987) Multivariate analysis of genetic exchanges between Solea segalensis (Teleosts, Soleidae). Biol J Linn Soc 32:357-371

Swearer SE, Sima JS, Hellberg ME, Thorrold SR and 6 others (2002) Evidence of self-recruitment in demersal marine populations. Bull Mar Sci 70:251-271

Vigliola L (1998) Contrôle et régulation du recrutement des Sparidae (Poissons, Teléostéens) an Méditerranée: importance des processus pré-et post-installation benthique. $\mathrm{PhD}$ dissertation, Université de la Méditerranée, Marseille

Waples RS (1998) Separating the wheat from the chaff: patterns of genetic differentiation in high gene flow species. Am Genet Assoc 89:438-450

Weir BS, Cockerham CC (1984) Estimating F-statistics for the analysis of population structure. Evolution 38:1358-1370

Whitehead PJP, Bauchot ML, Hureau JC, Nielsen J, Tortonese E (1986) Fishes of the North-Eastern Atlantic and the Mediterranean. I, II and III. UNESCO Press, Paris

Submitted: April 25, 2006; Accepted: August 18, 2006

Proofs received from author(s): February 22, 2007 